\title{
Effects of repetitive injections of hyaluronic acid on peritendinous adhesions after flexor tendon repair: a preliminary randomized, placebo-controlled clinical trial
}

\author{
Fleksör tendon onarım sonrası, tekrarlayan hyaluronik asit enjeksiyonlarının, \\ peritendinöz adezyon üzerine etkisi: Randomize plasebo kontrollü klinik ön çalışma
}

\author{
Güzin Yeşim ÖZGENEL, ${ }^{1}$ Abdullah ETÖZ ${ }^{2}$
}

\section{BACKGROUND}

The aim of this study was to investigate the efficacy of three injections of hyaluronic acid (HA) versus placebo (saline) over a two-week period on functional outcomes after zoneII flexor tendon repairs.

\section{METHODS}

Twenty-two patients with isolated zone-II flexor tendon injury of the index fingers were included in this study. Before tenorrhaphy, fingers were randomly divided into two groups; 11 were treated with three injections of HA around the tenorrhaphy site and 11 served as a placebo group and were treated with saline in the same way. The first dose was given at the time of tenorrhaphy and two additional doses were given at one-week intervals. A Kleinert rehabilitation protocol was employed postoperatively. Range of motion was assessed with total active and passive movement evaluation systems at 3 weeks, 3 months and long-term. Functional outcome was evaluated using the Strickland classification.

\section{RESULTS}

There were no differences between the two groups in terms of range of motion at 3 weeks. However, at 3 months and long-term, a significant improvement was observed in fingers treated with HA compared to placebo.

\section{CONCLUSION}

This preliminary placebo-controlled study suggests that repetitive injections of HA can improve clinical outcomes presumably due to the effect on decreasing adhesions in primary tendon repairs.

Key Words: Adhesion prevention; hyaluronic acid; tendon adhesions; tendon repair.

\begin{abstract}
$A M A C ̧$
$\mathrm{Bu}$ çalışmada, zon-II fleksör tendon onarımlarından sonra, iki haftalık süre içerisinde enjekte edilen 3 doz hyaluronik asit (HA) enjeksiyonunun plaseboya (salin) karşı etkinliği araştırıldı.
\end{abstract}

\section{GEREÇ VE YÖNTEM}

Çalışmaya İkinci parmak izole zon-II fleksör tendon hasarlanması olan 22 hasta dahil edildi. Tenorafi öncesi, parmaklar randomize olarak iki gruba ayrıldı; 11 parmakta tenorafi çevresine 3 doz HA enjekte edilirken, aynı şekilde salin enjekte edilen 11 parmak da plasebo grubunu oluşturdu. Birinci doz tenorafi sirasinda verildi ve ilave 2 doz 1 hafta ara ile enjekte edildi. Operasyon sonrası Kleinert rehabilitasyon protokolü uygulandı. Eklem hareket açıklığı, 3. hafta, 3. ay ve uzun dönemde total aktif ve pasif eklem açıklı̆̆ ölçülerek değerlendirildi. Fonksiyonel sonuç, Strickland sınıflandırmasına göre belirlendi.

\section{BULGULAR}

Üçüncü haftada eklem hareket açıklığı açısından iki grup arasinda bir fark tespit edilmedi. Ancak, 3. ay ve uzun dönemde, eklem hareket açıklığında, HA enjekte edilen parmaklarda plasebo grubuna göre anlamlı derecede iyileşme olduğu gözlendi.

\section{SONUÇ}

Bu plasebo kontrollü ön çalışmada, mükerrer HA enjeksiyonlarının, primer tendon onarımında, muhtemelen adezyon azaltıcı etkisine bağlı olarak, klinik sonuçları iyileştirebildiği ileri sürülmektedir.

Anahtar Sözcükler: Adezyon önleme; hyaluronik asit; tendon adezyonları; tendon onarımı.

\footnotetext{
${ }^{1}$ Department of Plastic, Reconstructive and Aesthetic Surgery, Division of Hand Surgery, Uludag University Faculty of Medicine, Bursa;

${ }^{2}$ Department of Plastic Surgery, Inegöl State Hospital, Bursa, Turkey.
} 
Despite advances in surgical techniques and improved postoperative rehabilitation programs, adhesions between the tendon and the surrounding tissues continue to be an important problem after primary flexor tendon repair, especially in zone II. ${ }^{[1-5]}$ Various pharmacologic agents have been used in an attempt to reduce peritendinous adhesions after flexor tendon surgery. ${ }^{[6-14]}$ One of these agents is hyaluronic acid (HA), a fibroblast-derived glycosaminoglycan. Previous experimental studies show that topical application of high molecular weight HA in high concentrations between an injured tendon and its sheath promotes tendon healing and decreases adhesion formation. ${ }^{[15-20]}$ In these experimental studies, the prevention of peritendinous adhesions was explained by the fact that HA created a scaffold around the tenorrhaphy site because of its high viscoelastic property. This macromolecular network would prevent fibrous ingrowth from the surrounding tissues. ${ }^{[21-23]}$ The other explanation was that HA, being an effective soft tissue lubricant, might decrease the new extracellular matrix formation due to the inhibition of mononuclear phagocytes and lymphocytes. ${ }^{[24]}$

The goal of this clinical study was to compare the effects of repetitive injections of HA with placebo on the functional outcome after primary digital zone- II flexor tendon repair.

\section{MATERIALS AND METHODS}

\section{Study Design}

A randomized, double-blind, placebo-controlled trial was performed to determine whether peritendinous adhesions decrease as a result of treatment with HA (Orthovisc; Anika Therapeutics, USA) as opposed to a physiologic saline solution (placebo). The study was approved by our institutional review board and all patients signed an informed-consent form before surgery.

\section{Patients}

From March 2002 to January 2005, 22 patients with a total of 22 flexor digitorum profundus (FDP) and 22 flexor digitorum superficialis (FDS) tendon transections of the index fingers caused by sharp instruments were operated. Specific characteristics of the patients, including gender, mean age, smoking, hand dominance, etiology, site of injury, and presence of digital nerve injury, are summarized in Table 1 . The two groups were similar in terms of age, sex, dominance of the injured hand, injury zone, and the number of the digits with nerve injury.

Fingers that were included in this clinical study were those that had a laceration of the FDP tendon, with a concomitant injury of the FDS tendon, in zone II of the index fingers, which had occurred within 24 hours prior to the surgery. Correspondingly, fingers that were excluded from this study were those that had a cutaneous defect at the repair site, a concomitant fracture, prior hand trauma, or congenital hand defect in order to avoid complications related to the wound site.

\section{Randomization}

Randomization was performed after it had been determined that the inclusion criteria had been met, but before the patient was taken to the operating room. The result of the randomization was not available to any of the involved clinicians or patients other than to the surgeon who performed the tendon repair and subsequently injected HA or saline solution. In all cases, the clinician injecting the test substance and the examiner performing the clinical evaluation were separate individuals.

\section{Surgical Procedure}

All operations were performed by one of the investigators in a standardized way under axillary block anesthesia and tourniquet control within the first 24 hours of injury. Both FDP and FDS tendons were approached through palmar zigzag incisions described by Brunner, and each FDP tendon was repaired with polypropylene suture (4-0 Prolene ${ }^{\circledR}$, Johnson \& John-

Table 1. Patient details*

\begin{tabular}{|c|c|c|}
\hline & $\begin{array}{c}\text { Treatment } \\
\text { group }\end{array}$ & $\begin{array}{l}\text { Placebo } \\
\text { group }\end{array}$ \\
\hline Total number of patients & 11 & 11 \\
\hline \multicolumn{3}{|l|}{ Gender } \\
\hline Male & 11 & 10 \\
\hline Female & - & 1 \\
\hline Mean age (range) (yr) & $28(21-35)$ & $31(26-36)$ \\
\hline \multicolumn{3}{|l|}{ Smoker } \\
\hline Yes & 9 & 11 \\
\hline No & 2 & - \\
\hline \multicolumn{3}{|l|}{ Dominant hand } \\
\hline Right & 10 & 9 \\
\hline Left & 1 & 2 \\
\hline \multicolumn{3}{|l|}{ Injured hand } \\
\hline Right & 10 & 9 \\
\hline Left & 1 & 2 \\
\hline \multicolumn{3}{|l|}{ Cause of injury } \\
\hline Knife & 3 & 4 \\
\hline Glass & 6 & 4 \\
\hline Saw & 2 & 3 \\
\hline \multicolumn{3}{|l|}{ Site of injury } \\
\hline Proximal to A2 pulley & - & - \\
\hline Under A2 pulley & 3 & 3 \\
\hline Distal to A2 pulley & 8 & 8 \\
\hline \multicolumn{3}{|c|}{ Number of digits with nerve injury } \\
\hline Injured & 9 & 8 \\
\hline Repaired & 9 & 8 \\
\hline
\end{tabular}

* Demographic data for 22 patients 
son, Switzerland) using the modified Kessler technique, followed by an epi-tendinous running suture (6-0 Prolene ${ }^{\circledR}$, Johnson \& Johnson, Switzerland). The injured FDS tendon was treated in the same way as the FDP tendon. In all cases, the membranous portion of the flexor tendon sheath was sutured. The management of the pulley system of flexor tendon sheath was performed according to the site of the tendon injury. When the cut was a little distal to the A2 pulley, the distal one-third of the A2 pulley was released. When the tendon was repaired under the middle and proximal part of the A2 pulley, half of the A2 pulley was divided. When the tendon cut was at the level of the A3 pulley, all annular pulleys were preserved. When the cut was between the proximal interphalangeal (PIP) joint and A4 pulley, only the A3 pulley was divided. In addition, all associated digital nerve divisions were repaired with polypropylene suture (10-0 Prolene ${ }^{\mathbb{B}}$, Johnson \& Johnson, Switzerland).

Before closing the wound, the catheter $(23 \mathrm{G} \times 3 / 4$ inch, Vacuette $\left.{ }^{\circledR}\right)$ tip was placed closest to the FDP tenorrhaphy site adjacent to the closed flexor tendon sheath and threaded subcutaneously, exiting the skin at the level of the A1 pulley just like a suction drain, and it was fixed to the skin at the exit point by a suture in order to maintain the catheter tip adjacent to the tenorrhaphy site. After closing the wound, in the treatment group, $0.4 \mathrm{ml}$ of high molecular weight HA (1.0-2.9 million Daltons) in high concentrations (15 $\mathrm{mg} / \mathrm{ml}$ ) was injected through the catheter, and then the end of the catheter was covered with a tap. In the placebo group, an equivalent volume of physiologic saline solution was administered in the same way. Next, a sterile dressing was applied, followed by a dorsal plaster splint, extending from beyond the fingertip to the proximal forearm. The wrist was held in approximately $30^{\circ}$ palmar flexion, the metacarpophalangeal (MCP) joints were flexed approximately $60^{\circ}$ and the PIP and distal interphalangeal (DIP) joints were flexed $0^{\circ}$. The splint allowed full extension of the PIP and DIP joints.

After surgery, two injections were given through the inserted catheter at one-week intervals and at the completion of the injections, the catheter was withdrawn. The skin sutures were removed on the 10th day.

\section{Post-Operative Follow-Up}

All operated fingers had similar postoperative care. Rehabilitation was started on the 3rd postoperative day with a passive flexion and active extension protocol according to the method of Kleinert and continued for the first 4 weeks. ${ }^{[25,26]}$ At the 5 th week, the plaster splint was removed and active flexion was started.

All patients were followed by the same blinded clinician (twice a week for the first 12 weeks and then once at 6 months). Each visit included visual inspection and physical examination of the operated finger and assessment for signs of wound dehiscence or infection. Range of motion of MCP, PIP and DIP joints of each finger was measured using a goniometer at 3 weeks, 3 months and long-term (range: 58-91 months) after the surgery. Range of motion values for passive and active movements of three joints in each finger were summed up and recorded as the total range of passive motion (TPM) and the total range of active motion (TAM). The revised Strickland grading system (Strickland, 1985) was used to assess the final active motion of each operated finger at the long-term followup. The active motion value was found by subtracting the extension deficit of the involved joints from the maximal possible flexion. Results were classified as excellent $\left(>131^{\circ}\right)$, good $\left(88-131^{\circ}\right)$, fair $\left(44-87^{\circ}\right)$ and poor $\left(<44^{\circ}\right)$.

\section{Statistical Analysis}

The Mann-Whitney U test was performed for unpaired groups and categorical variables were analyzed by Fisher's exact test. A p value less than 0.05 was considered statistically significant.

\section{RESULTS}

All patients complied with the rehabilitation protocol. During the first two weeks, there was a limited range of active and passive movements in each group because of pain and swelling. After two weeks, pain and swelling decreased and the range of motions increased gradually. No adverse events such as discomfort at the injection site and/or localized swelling were seen in any of the patients. HA did not produce any clinical signs of inflammation. On gross examination, all operated fingers appeared to be free of infection. No flexion contracture developed. Tendon rupture was not seen in any of the cases.

\section{Placebo Group}

The TPM value for the saline-treated group was $155.9^{\circ}$ (19.6) (range: $110-175^{\circ}$ ) at postoperative 3 weeks and increased to $177.7^{\circ}$ (23.3) (range: 120 $200^{\circ}$ ) at 3 months and $181.8^{\circ}(20.2)$ (range: $130-200^{\circ}$ ) at long-term. The TAM value was measured as $107.3^{\circ}$ (18.4) $\left(110-175^{\circ}\right)$ at 3 weeks and found to increase to $141.4^{\circ}(21.7)\left(120-200^{\circ}\right)$ at the end of the 3rd month and $147.7^{\circ}(19.5)\left(110-170^{\circ}\right)$ at long-term. In 11 fingers, 7 were rated as good and 4 as fair according to the revised Strickland classification system (Table 2). ${ }^{[27]}$

\section{Treatment Group}

The TPM value for the HA-treated group was $167.7^{\circ}(21.8)\left(120-195^{\circ}\right)$ at postoperative 3 weeks and increased to $212.3^{\circ}(33.5)(140-240)$ at 3 months and $217.7^{\circ}(26.9)\left(160-240^{\circ}\right)$ at long-term. The TAM value was measured as $118.6^{\circ}(15.3)\left(90-135^{\circ}\right)$ at 3 weeks 
Table 2. Length of follow-up information and functional outcomes calculated using the revised Strickland classification system for each patient

\begin{tabular}{|c|c|c|c|c|c|}
\hline \multicolumn{3}{|c|}{ Placebo group } & \multicolumn{3}{|c|}{ Treatment group } \\
\hline Patient & $\begin{array}{l}\text { Duration of follow-up } \\
\text { (months) }\end{array}$ & Strickland & Patient & $\begin{array}{l}\text { Duration of follow-up } \\
\text { (months) }\end{array}$ & Strickland \\
\hline 1 & 58 & Good & 1 & 59 & Excellent \\
\hline 2 & 59 & Fair & 2 & 60 & Good \\
\hline 3 & 60 & Good & 3 & 60 & Good \\
\hline 4 & 60 & Good & 4 & 60 & Good \\
\hline 5 & 61 & Good & 5 & 61 & Excellent \\
\hline 6 & 59 & Fair & 6 & 62 & Good \\
\hline 7 & 91 & Good & 7 & 85 & Good \\
\hline 8 & 62 & Fair & 8 & 62 & Excellent \\
\hline 9 & 61 & Fair & 9 & 61 & Good \\
\hline 10 & 65 & Good & 10 & 65 & Good \\
\hline 11 & 60 & Good & 11 & 61 & Good \\
\hline Mean \pm SD & $63 \pm 2$ & & Mean \pm SD & $63 \pm 2$ & \\
\hline Range & $58-91$ & & Range & $59-85$ & \\
\hline
\end{tabular}

and was found to increase to $166.4^{\circ}(14.8)\left(135-185^{\circ}\right)$ at the end of the 3rd month and $176.4^{\circ}$ (12.7) (150$\left.190^{\circ}\right)$ at long-term. In 11 fingers, 3 were rated as excellent and 8 as good according to the revised Strickland classification system (Table 2). ${ }^{[27]}$

\section{Comparison}

There was no statistically significant difference in TPM and TAM values between the two groups at 3 weeks after surgery $(\mathrm{p}>0.05)$. However, at 3 months and long-term, a significant increase was observed in the total values of the passive and active range of motions of the fingers treated with HA compared with the fingers treated with saline $(p<0.05)$ (Figs. 1, 2). The assessment of range of motion using the revised Strickland classification system gave 3/11 excellent and 8/11 good results in the HA-treated group compared with $7 / 11$ good results in the placebo group (Table 2).

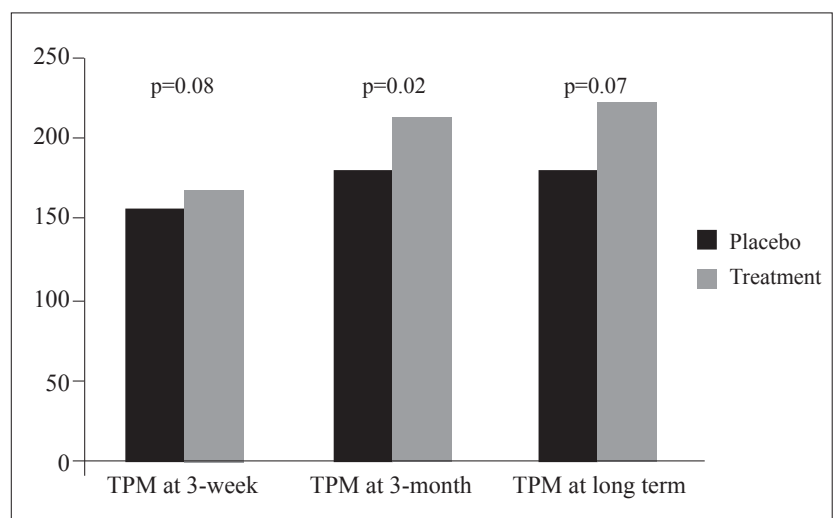

Fig. 1. Comparison of the results of total passive range of joint motions (degrees).

\section{DISCUSSION}

The main problem after flexor tendon surgery is the formation of adhesions between the tendon and the tendon sheath or other tissues that restricts tendon gliding. Several different types of interpositional materials, both biologic and synthetic, have been used as a barrier around the site of tendon repair. ${ }^{[28,29]}$ These isolation techniques have generally been unsuccessful. Some of them were found to cause impairment of the tendon healing process and some materials stimulated a severe inflammatory response. Various pharmacologic agents such as 5-fluorouracil, indomethacin and ibuprofen have been proposed. ${ }^{[10-12,14]}$ Prostaglandin inhibitors, such as indomethacin and ibuprofen, may decrease the endogenous local damage by reducing the pro-inflammatory agents. The consequence could be a decrease in peritendinous fibroplasia. Steroids, antihistamines and beta-aminopropionitrile have shown

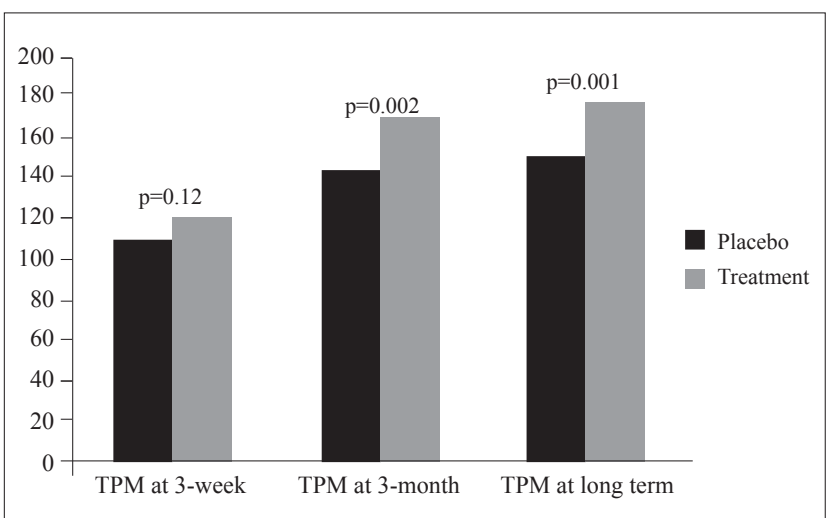

Fig. 2. Comparison of the results of total active range of joint motions (degrees). 
experimental promise, but cannot be used clinically because of toxicity or impairment of wound healing. [7,8,13] Additionally, aprotinin and 5-fluorouracil have been used with variable results. ${ }^{[9,11]}$ Human amniotic fluid has some type of inhibitory effect on fibroblast proliferation. It was shown that the least adhesion and the best healing were observed in tendons treated with human amniotic fluid application. ${ }^{[30]}$ However, no human trial has been reported.

Recently, there has been a great interest in HA, which is richly found in the extracellular matrix of soft connective tissues and synovial fluids in the human body. ${ }^{[31]}$ HA provides a healing process through regeneration and growth rather than scarring and fibrosis. ${ }^{[21,22]}$ However, this effect has been variable. ${ }^{[32]}$ The molecular weight and the concentration of the preparation are critical to its potential beneficial effects. Low concentration and low molecular weight seem to have a stimulating effect on granulocyte function. ${ }^{[33]}$ In contrast, high concentration and high molecular weight HA inhibits the movements and phagocytosis of granulocytes. ${ }^{[34,35]}$ It was found that the critical molecular weight seems to be around $10^{5}$ to $10^{6}$ Daltons for inhibition of granulocyte function. ${ }^{[15]}$ In this present study, Orthovisc (Anika Therapeutics, USA) was used. The molecular weight and the concentration of hyaluronan in Orthovisc was about 106 Daltons and $15 \mathrm{mg} / \mathrm{ml}$.

Several experimental studies have claimed that exogenously administered sodium hyaluronate helps to prevent the formation of postoperative adhesions after flexor tendon repair in zone II without interfering with healing. ${ }^{[15,17-20,36]}$ The first prospective, double-blind, randomized clinical study about the HA effect on prevention of adhesions in hand surgery was performed by Hagberg. ${ }^{[36]}$ In that study, Hagberg did not demonstrate any significant benefit of single-dose injection of HA into the tendon sheath after flexor tendon repair in limiting adhesions. We believe this to be due to the rapid elimination of single-dose application of the HA preparation around the sites of tendon repair. Additionally, the wound would dilute the effectiveness of the HA solution. In order to overcome these limitations, in this clinical study, we preferred three injections of HA. The first injection was given at the time of the repair and two additional doses were given at one-week intervals. Therefore, we provided the maintenance of sufficient amounts of HA around the tenorrhaphy site during the first two weeks, which is defined as a critical period for peritendinous adhesions. A one-week interval was chosen because it was shown that HA was eliminated within 7 days. ${ }^{[15,30,31]}$

This clinical study compared HA to saline. The concentration of electrolytes in normal saline solution $(0.9 \% \mathrm{NaCl})$ is similar to that of blood and it is meta- bolically inert (Hoppe et al., 2010). Therefore, saline does not create an inferior environment for the tendons and in the majority of the experimental and clinical studies, saline is used as placebo. ${ }^{[36-38]}$ However, a study that had both placebo and untreated groups (simply leaving the catheter in) can be planned in order to distinguish the placebo effect.

Postoperative rehabilitation methods improve the clinical outcomes in flexor tendon surgery by reducing the peritendinous adhesions and providing more tensile strength by favoring tendon nutrition and intrinsic tendon healing. ${ }^{[4]}$ However, early active mobilization protocols may increase the repair site elongation and rupture rates. ${ }^{[39,40]}$ In order to solve these problems, many multi-strand tendon suture techniques have been described. ${ }^{[41,42]}$ Experimental studies have shown that suture strength and resistance to repair site gap formation increase with the number of suture strands crossing the tendon repair site. ${ }^{[43-45]}$ However, this makes the suture techniques more complex and increases the difficulty of using these configurations in clinical cases. On the other hand, multi-strand repairs may increase the peritendinous adhesions and damage the nutrition in the tendon ends. In addition, if appropriate pulleys are not released during the flexor tendon surgery, multi-strand repairs alone cannot eliminate the danger of tendon rupture. ${ }^{[46]}$ For these reasons, we preferred to use the modified Kessler suture technique. This conventional two-strand repair augmented with a peripheral suture provides sufficient gap resistance and tensile strength that may be able to withstand early active mobilization after flexor tendon repair. In addition, the material used for core and peripheral suture, length of the core suture purchase and depth and length of the peripheral suture purchase are the other factors that affect the results of the tendon surgery. ${ }^{[42]}$ In this clinical study, a peripheral suture was placed deep into the tendon instead of superficially only through the epitenon and $2 \mathrm{~mm}$ from the cut tendon ends in order to increase the repair site strength.

Strickland classification ${ }^{[27]}$ is most commonly used evaluation system especially for zone-II flexor tendon repairs. ${ }^{[27,44,46-49]}$ In this article, functional status was evaluated using the revised Strickland classification system. The fingers treated with HA showed $27 \%$ excellent and $73 \%$ good results, whereas fingers treated with saline showed $64 \%$ good and $36 \%$ fair results. As a result, HA-treated fingers showed superior results compared with the saline-treated fingers.

In conclusion, this preliminary clinical study shows that repetitive injections of HA around the tenorrhaphy site after flexor tendon surgery reduces the formation of restrictive adhesions. However, large series are needed in order to support the results of this clinical study. 


\section{Acknowledgements}

We thank İlker ERCAN for support with the statistical analysis. No benefits in any form have been received related to the subject of this article.

\section{REFERENCES}

1. Gelberman RH, Manske PR, Akeson WH, Woo SL, Lundborg G, Amiel D. Flexor tendon repair. J Orthop Res 1986;4:11928. CrossRef

2. Gelberman RH, Manske PR. Factors influencing flexor tendon adhesions. Hand Clin 1985;1:35-42.

3. Jansen CW, Watson MG. Measurement of range of motion of the finger after flexor tendon repair in zone II of the hand. J Hand Surg Am 1993;18:411-7. CrossRef

4. Manske PR. Flexor tendon healing. J Hand Surg $\mathrm{Br}$ 1988;13:237-45. CrossRef

5. Matthews P, Richards H. Factors in the adherence of flexor tendon after repair: an experimental study in the rabbit. J Bone Joint Surg Br 1976;58:230-6.

6. Golash A, Kay A, Warner JG, Peck F, Watson JS, Lees VC. Efficacy of ADCON-T/N after primary flexor tendon repair in Zone II: a controlled clinical trial. J Hand Surg Br 2003;28:113-5. CrossRef

7. Kapetanos G. The effect of the local corticosteroids on the healing and biomechanical properties of the partially injured tendon. Clin Orthop Relat Res 1982;163:170-9.

8. Ketchum LD. Effects of triamcinolone on tendon healing and function. A laboratory study. Plast Reconstr Surg 1971;47:471-82. CrossRef

9. Komurcu M, Akkus O, Basbozkurt M, Gur E, Akkas N. Reduction of restrictive adhesions by local aprotinin application and primary sheath repair in surgically traumatized flexor tendons of the rabbit. J Hand Surg Am 1997;22:826-32. CrossRef

10. Kulick MI, Smith S, Hadler K. Oral ibuprofen: evaluation of its effect on peritendinous adhesions and the breaking strength of a tenorrhaphy. J Hand Surg Am 1986;11:110-20.

11. Moran SL, Ryan CK, Orlando GS, Pratt CE, Michalko KB. Effects of 5-fluorouracil on flexor tendon repair. J Hand Surg Am 2000;25:242-51. CrossRef

12. Nishimura K, Nakamura RM, diZerega GS. Ibuprofen inhibition of postsurgical adhesion formation: a time and dose response biochemical evaluation in rabbits. J Surg Res 1984;36:115-24. CrossRef

13. Speer DP, Feldman S, Chvapil M. The control of peritendinous adhesions using topical beta-aminopropionitrile base. J Surg Res 1985;38:252-7. CrossRef

14. Szabo RM, Younger E. Effects of indomethacin on adhesion formation after repair of zone II tendon lacerations in the rabbit. J Hand Surg Am 1990;15:480-3. CrossRef

15. Amiel D, Ishizue K, Billings E Jr, Wiig M, Vande Berg J, Akeson $\mathrm{WH}$, et al. Hyaluronan in flexor tendon repair. J Hand Surg Am 1989;14:837-43. CrossRef

16. Hagberg L, Tengblad A, Gerdin B. Hyaluronic acid in flexor tendon sheath fluid after sheath reconstructions in rabbits. A comparison between tendon sheath transplantation and conventional two stage procedures. Scand J Plast Reconstr Surg Hand Surg 1991;25:103-7. CrossRef

17. Nishida J, Araki S, Akasaka T, Toba T, Shimamura T, Amadio PC, Effect of hyaluronic acid on the excursion resistance of tendon grafts. A biomechanical study in a canine model in vitro. J Bone Joint Surg Br 2004;86:918-24. CrossRef

18. Ozgenel GY. The effects of a combination of hyaluronic and amniotic membrane on the formation of peritendinous adhe- sions after flexor tendon surgery in chickens. J Bone Joint Surg Br 2004;86:301-7. CrossRef

19. St Onge R, Weiss C, Denlinger JL, Balazs EA. A preliminary assessment of Na-hyaluronate injection into "no man's land" for primary flexor tendon repair. Clin Orthop Relat Res 1980;146:269-75.

20. Tuncay I, Ozbek H, Atik B, Ozen S, Akpinar F. Effects of hyaluronic acid on postoperative adhesion of tendo calcaneus surgery: an experimental study in rats. J Foot Ankle Surg 2002;41:104-8. CrossRef

21. Burd DA, Greco RM, Regauer S, Longaker MT, Siebert JW, Garg HG. Hyaluronan and wound healing: a new perspective. Br J Plast Surg 1991;44:579-84. CrossRef

22. Longaker MT, Adzick NS. The biology of fetal wound healing: a review. Plast Reconstr Surg 1991;87:788-98. CrossRef

23. Longaker MT, Chiu ES, Harrison MR, Crombleholme TM, Langer JC, Duncan BW, et al. Studies in fetal wound healing. IV. Hyaluronic acid-stimulating activity distinguishes fetal wound fluid from adult wound fluid. Ann Surg 1989;210:66772. CrossRef

24. Swann DA, Bloch KJ, Swindell D, Shore E. The lubricating activity of human synovial fluids. Arthritis Rheum 1984;27:552-6. CrossRef

25. Lister GD, Kleinert HE, Kutz JE, Atasoy E. Primary flexor tendon repair followed by immediate controlled mobilization. J Hand Surg Am 1977;2:441-51.

26. Kitsis CK, Wade PJ, Krikler SJ, Parsons NK, Nicholls LK. Controlled active motion following primary flexor tendon repair: a prospective study over 9 years. J Hand Surg Br 1998;23:344-9. CrossRef

27. Strickland JW. Results of flexor tendon surgery in zone II. Hand Clin 1985;1:167-79.

28. Menderes A, Mola F, Tayfur V, Vayvada H, Barutçu A. Prevention of peritendinous adhesions following flexor tendon injury with seprafilm. Ann Plast Surg 2004;53:560-4. CrossRef

29. Stark HH, Boyes JH, Johnson L, Ashworth CR. The use of paratenon, polyethylene film, or silastic sheeting to prevent restricting adhesions to tendons in the hand. J Bone Joint Surg Am 1977;59:908-13.

30. Ozgenel GY, Samli B, Ozcan M. Effects of human amniotic fluid on peritendinous adhesion formation and tendon healing after flexor tendon surgery in rabbits. J Hand Surg Am 2001;26:332-9. CrossRef

31. Swann DA, Radin EL, Nazimiec M, Weisser PA, Curran N, Lewinnek G. Role of hyaluronic acid in joint lubrication. Ann Rheum Dis 1974;33:318-26. CrossRef

32. Rydell N. Decreased granulation tissue reaction after installment of hyaluronic acid. Acta Orthop Scand 1970;41:307-11.

33. Håkansson L, Hällgren R, Venge P. Regulation of granulocyte function by hyaluronic acid. In vitro and in vivo effects on phagocytosis, locomotion, and metabolism. J Clin Invest 1980;66:298-305. CrossRef

34. Brown AF. Neutrophil granulocytes: adhesion and locomotion on collagen substrata and in collagen matrices. J Cell Sci 1982;58:455-67.

35. Pisko EJ, Turner RA, Soderstrom LP, Panetti M, Foster SL, Treadway WJ. Inhibition of neutrophil phagocytosis and enzyme release by hyaluronic acid. Clin Exp Rheumatol 1983;1:41-4.

36. Hagberg L. Exogenous hyaluronate as an adjunct in the prevention of adhesions after flexor tendon surgery: a controlled clinical trial. J Hand Surg Am 1992;17:132-6. CrossRef

37. Dogramaci Y, Kalac A, Atik E, Esen E, Altuğ ME, Onel E, 
et al. Effects of a single application of extractum cepae on the peritendinous adhesion: an experimental study in rabbits. Ann Plast Surg 2010;64:338-41. CrossRef

38. Jubb RW, Piva S, Beinat L, Dacre J, Gishen P. A one-year, randomised, placebo (saline) controlled clinical trial of 500-730 kDa sodium hyaluronate (Hyalgan) on the radiological change in osteoarthritis of the knee. Int J Clin Pract 2003;57:467-74.

39. Corradi M, Bellan M, Frattini M, Concari G, Tocco S, Pogliacomi F. The four-strand staggered suture for flexor tendon repair: in vitro biomechanical study. J Hand Surg Am 2010;35:948-55. CrossRef

40. Harris SB, Harris D, Foster AJ, Elliot D. The aetiology of acute rupture of flexor tendon repairs in zones 1 and 2 of the fingers during early mobilization. J Hand Surg $\mathrm{Br}$ 1999;24(3):275-80. CrossRef

41.Hoffmann GL, Büchler U, Vögelin E. Clinical results of flexor tendon repair in zone II using a six-strand double-loop technique compared with a two-strand technique. J Hand Surg Eur Vol 2008;33:418-23. CrossRef

42. Kim HM, Nelson G, Thomopoulos S, Silva MJ, Das R, Gelberman RH. Technical and biological modifications for enhanced flexor tendon repair. J Hand Surg Am 2010;35:10318. CrossRef
43. Kubota H, Aoki M, Pruitt DL, Manske PR. Mechanical properties of various circumferential tendon suture techniques. J Hand Surg Br 1996;21:474-80. CrossRef

44. Osada D, Fujita S, Tamai K, Yamaguchi T, Iwamoto A, Saotome K. Flexor tendon repair in zone II with 6-strand techniques and early active mobilization. J Hand Surg Am 2006;31:987-92. CrossRef

45. Winters SC, Gelberman RH, Woo SL, Chan SS, Grewal R, Seiler JG 3rd. The effects of multiple-strand suture methods on the strength and excursion of repaired intrasynovial flexor tendons: a biomechanical study in dogs. J Hand Surg Am 1998;23:97-104. CrossRef

46. Elliot D. Primary flexor tendon repair--operative repair, pulley management and rehabilitation. J Hand Surg $\mathrm{Br}$ 2002;27:507-13. CrossRef

47. Kleinert HE, Verdan C. Report of the Committee on Tendon Injuries (International Federation of Societies for Surgery of the Hand). J Hand Surg Am 1983;8:794-8.

48. Jansen CW, Watson MG. Measurement of range of motion of the finger after flexor tendon repair in zone II of the hand. J Hand Surg Am 1993;18:411-7. CrossRef

49. Tang JB. Indications, methods, postoperative motion and outcome evaluation of primary flexor tendon repairs in Zone 2. J Hand Surg Eur Vol 2007;32:118-29. CrossRef 